http://jmscr.igmpublication.org/home/

ISSN (e)-2347-176x ISSN (p) 2455-0450

crossref DOI: https://dx.doi.org/10.18535/jmscr/v7i10.164

Journal Of Medical Science And Clinical Research

IGM Publication

An Official Publication of IGM Publication

\title{
Ocular Disability Profile at a Hilly District Hospital of Northern India
}

\author{
Authors \\ Dr Arti Sareen ${ }^{1 *}$, Dr Mudita Gupta ${ }^{2}$, Dr Mukta Sharma ${ }^{3}$, Dr Kusum Bhanoo ${ }^{4}$ \\ ${ }^{1}$ Medical Officer, DDUZH, Shimla \\ ${ }^{2}$ Assistant Professor, Department of Dermatology, IGMC, Shimla \\ ${ }^{3}$ Medical Officer, DDUZH, Shimla \\ ${ }^{4}$ Bhanoo Hospital, Near College Gate, Dhalpur, Kullu \\ *Corresponding Author \\ Dr Arti Sareen
}

\begin{abstract}
Aim: To study the various causes and severity of visual handicap at a District Hospital of Northern India, in accordance with the disability certificate issued over a period of three months.

Material and Methods: Records of patients obtaining visual handicap certificates were studied in detail w.e.f. 1st July to 30th September, 2019. Patients were then categorized according to their age, sex, causes and degree of visual handicap and also whether they were issued a permanent or temporary certificate.

Results: The total number of disability certificates issued over a period of three months were 59. Of these 20 patients were issued a temporary certificate and 39 patients were issued a permanent certificate. The mean age of the patients was 42.3. 1 10.4 years. Out of these 41 patients were males and 18 patients were females. The major causes of visual disability were pthisisbulbi, optic atrophy and chorioretinal disorders.

Conclusion: Early diagnosis and timely management of common causes of visual disability in our set up could decrease the need for visual disability certification.

Keywords: Visual handicap, disability, disability certificate.
\end{abstract}

\section{Introduction}

Blindness, a major health problem in India ${ }^{1}$ has its prevalence still on the increase. ${ }^{2}$ The visual disability certificate is a part of the rehabilitative services to the blind. It provide certain concessions or benefits to the concerned individual who have disability of over $40 \% .^{3}$

The present study was designed to ascertain the causes and severity of visual impairment in our set up as no such study has been documented till date from our area. This will not only help in the future planning of strategies for the rehabilitation but in their prevention in the first place.

\section{Material and Methods}

People obtaining visual handicap certificate at DDU, ZH, Shimla (from 1st July to 31st September, 2019) were retrospectively analyzed as to the causes and severity of visual handicap. The percentage of disability was calculated based on the guidelines issued by the Government of India in 2018 by the Ministry of Social Justice and Empowerment. Patients who came for visual disability certificate were examined in detail with reference to their history, complete ocular examination and special investigations as and when required. The patients were studied in relation to their age, sex, type of disability. They 
were then categorized into temporary and permanent disability, the degree of visual handicap (mild, moderate, severe and profound), the causes of visual handicap.

\section{Results}

A total of 59 patients were issued the visual disability certificate during the period of study.
The mean age of the patients was 42.3. 10.4. There were 41 males and 18 females with a male: female ratio of 2.28:1. Majority of the patients (35.6\%) were in age group of 41-60 years followed by $21-40$ years $(28.8 \%)$ The sex and age distribution of the patients studied were as shown in Figure 1

Figure 1: Showing age and sex distribution of patients with disability

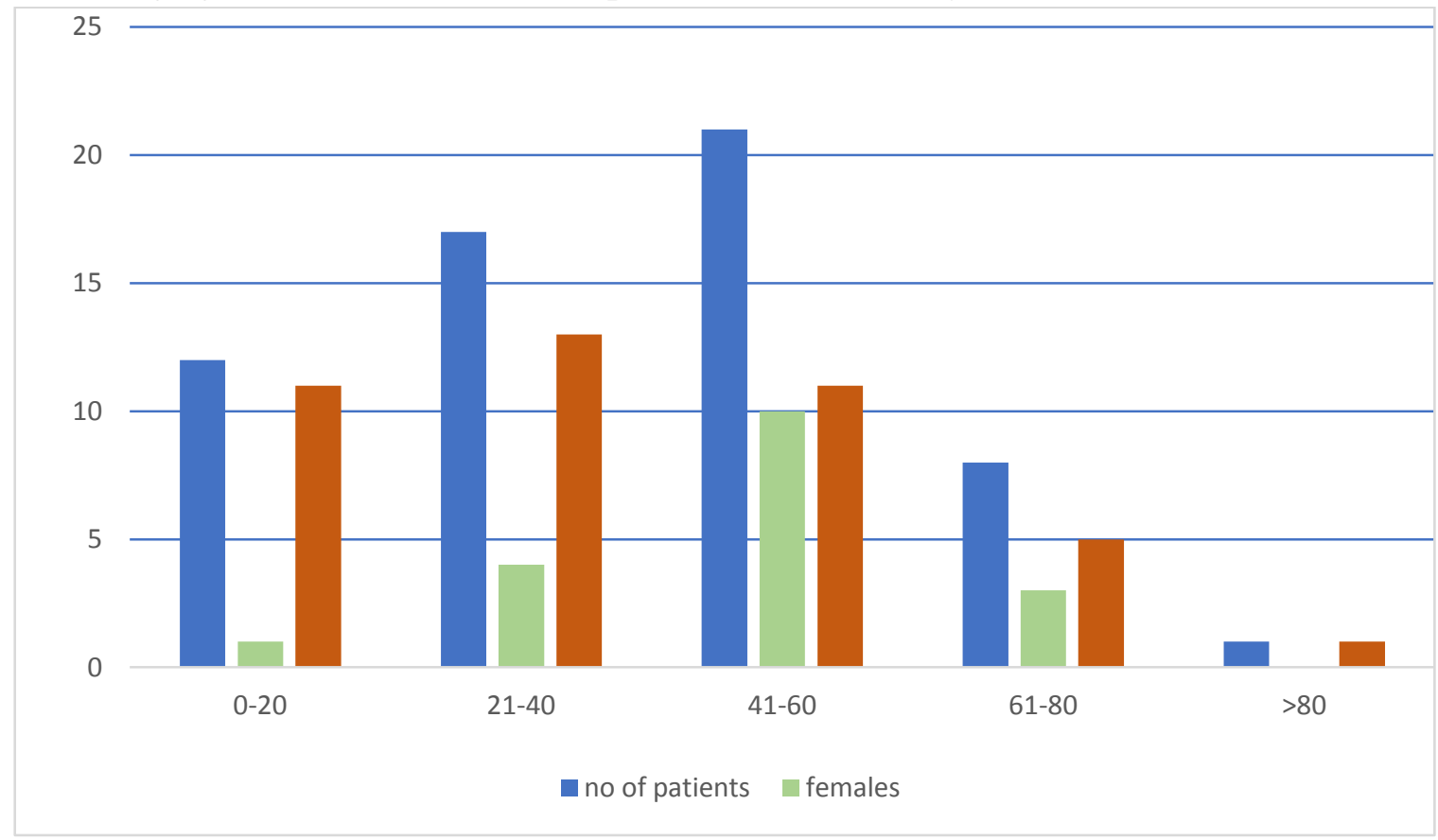

The visual acuity was categorised as shown in Table 1 (as per the guidelines issued by the
Government of India in 2018). Majority of the patients had $40 \%$ disability $(52.5 \%)$.

Table 1: Showing visual acuity distribution in both eyes in patient who were given disability certificate

\begin{tabular}{|c|c|c|c|c|c|c|}
\hline $\begin{array}{l}\text { Serial } \\
\text { number }\end{array}$ & Better eye & Worst eye & $\begin{array}{l}\text { Percent } \\
\text { impaired }\end{array}$ & $\begin{array}{l}\text { Disability } \\
\text { category }\end{array}$ & $\begin{array}{c}\text { Number of } \\
\text { patients }\end{array}$ & $\begin{array}{l}\text { Percentage } \\
\text { of patients }\end{array}$ \\
\hline 1 & $6 / 6$ to $6 / 18$ & $\begin{array}{c}6 / 6 \text { to } 6 / 18 \\
6 / 24 \text { to } 6 / 60 \\
<6160 \text { to } 3 / 60 \\
<3 / 60 \text { to no light } \\
\text { perception }\end{array}$ & $\begin{array}{c}0 \\
10 \\
20 \\
30 \\
\end{array}$ & $\begin{array}{l}0 \\
0 \\
\text { I }\end{array}$ & $\begin{array}{l}0 \\
0 \\
0 \\
10\end{array}$ & $\begin{array}{c}0 \\
0 \\
0 \\
16.9 \\
\end{array}$ \\
\hline 2 & $6 / 24$ to $6 / 60$ & $\begin{array}{c}6 / 24 \text { to } 6 / 60 \\
<6 / 60 \text { to } 3 / 60 \\
<3 / 60 \text { to no light } \\
\text { perception }\end{array}$ & $\begin{array}{l}40 \\
50 \\
60 \\
\end{array}$ & $\begin{array}{l}\text { IIIa } \\
\text { IIIb } \\
\text { IIIc } \\
\end{array}$ & $\begin{array}{c}31 \\
0 \\
6 \\
6\end{array}$ & $\begin{array}{c}52.5 \\
0 \\
\\
10.1 \\
\end{array}$ \\
\hline 3 & $<6 / 60$ to $3 / 60$ & $\begin{array}{c}<6 / 60 \text { to } 3 / 60 \\
<3 / 60 \text { to no light } \\
\text { perception }\end{array}$ & $\begin{array}{l}70 \\
80\end{array}$ & $\begin{array}{l}\text { IIId } \\
\text { IIIe }\end{array}$ & $\begin{array}{l}0 \\
2\end{array}$ & $\begin{array}{c}0 \\
3.4\end{array}$ \\
\hline 4 & $<3 / 60$ to $1 / 60$ & $\begin{array}{c}<3 / 60 \text { to no light } \\
\text { perception }\end{array}$ & 90 & IVa & 5 & 8.5 \\
\hline 5 & $\begin{array}{c}\text { Only HMCF } \\
\text { Or light perception } \\
\text { No light perception } \\
\end{array}$ & $\begin{array}{c}\text { Only HMCF } \\
\text { Or light perception } \\
\text { No light perception }\end{array}$ & 100 & $\mathrm{IVb}$ & 5 & 8.5 \\
\hline
\end{tabular}


Figure 2: Showing distribution of type of visual disability

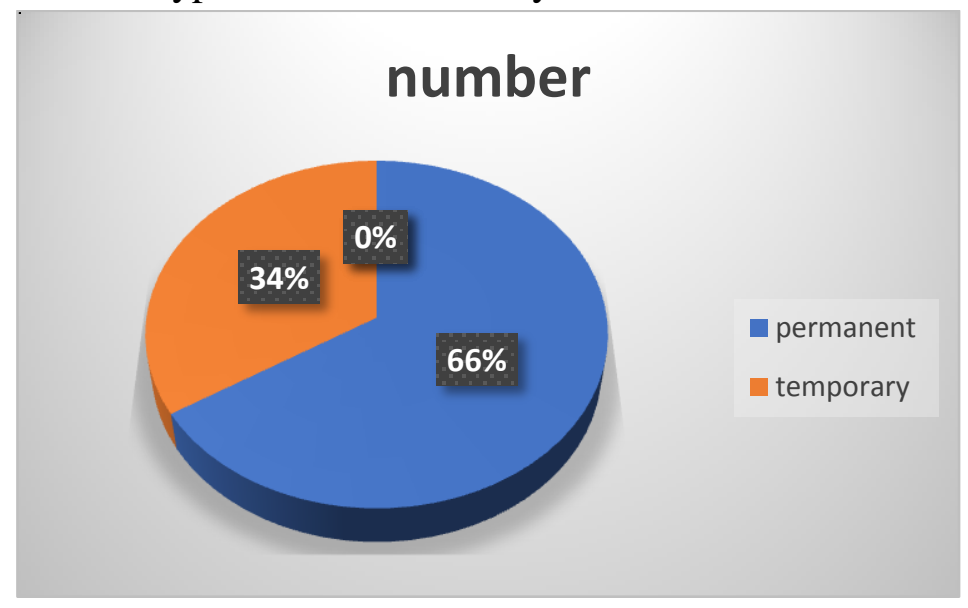

Pthisisbulbi 23.7\%) was the commonest cause of amblyopia (16.9\%).The causes of visual disability disability, followed by optic atrophy $(18.6 \%)$ and were as shown in Figure 3

Figure 3: Showing causes of visual disability

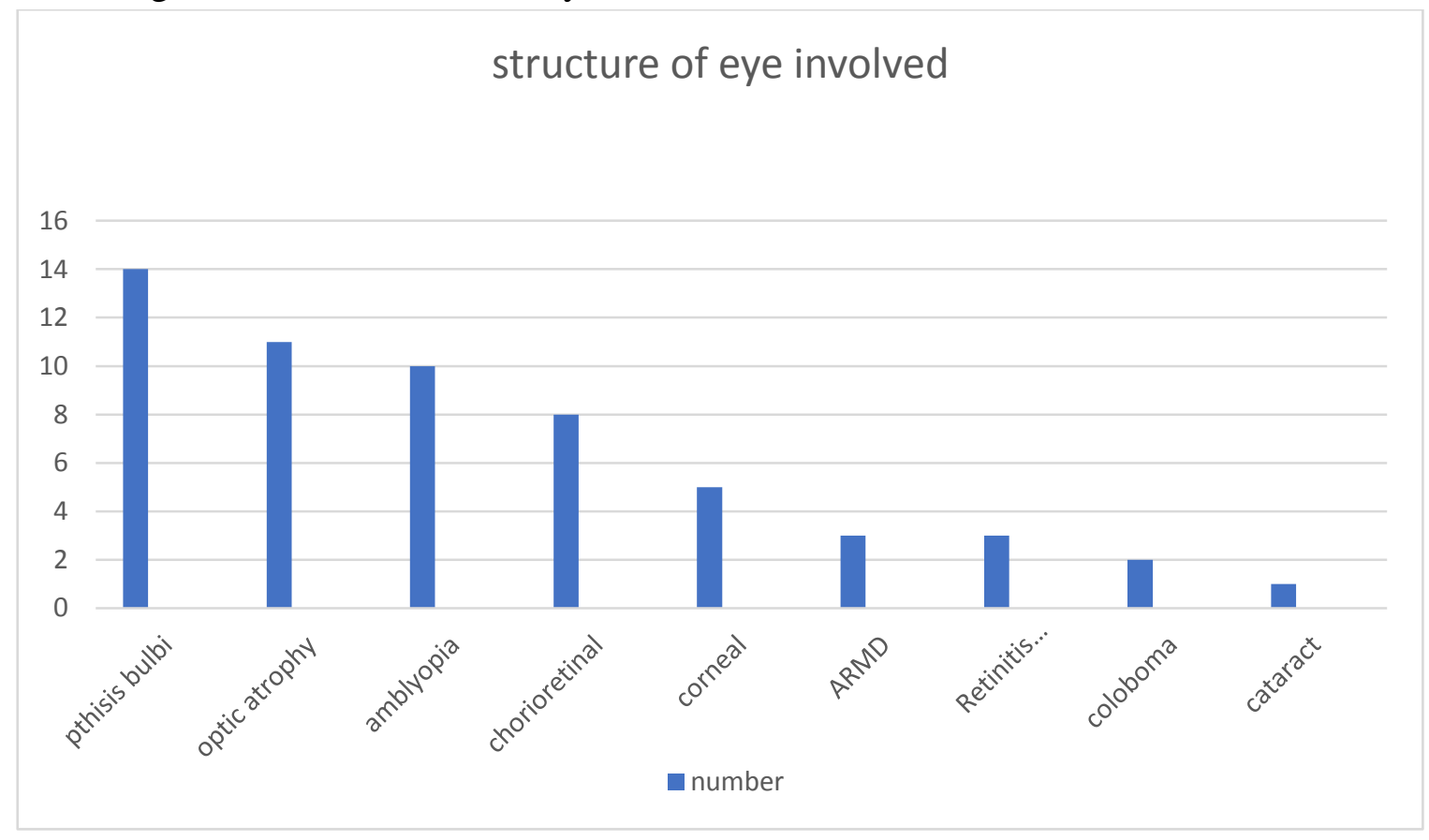

\section{Discussion}

According to WHO estiamtes the number of blind in the world is around 36 million and people with moderate to severe visual impairment are around 217 million with $90 \%$ of this blindness being in the low and middle income countries. ${ }^{4}$ There are about 9 blind people/1000 populations in Asia. The Sb-Saharan Africa, India and other Asia have a regional burden of blindness (RBB) ratio of greater then unity. ${ }^{5}$ Many studies have been conducted not only in India ${ }^{6,7}$ but other countries ${ }^{8,9}$ as well which have shown the prevalance of blindness in the community.

Also there have been studies in India which have studied the profile of patients obtaining visual disability certificates. ${ }^{2,10,11}$ We need to study the various causes as well severity of visual disability which will not only help plan the low vision care and rehabilitative services but also help in the planning of preventive strategies which in turn will help decrease the prevalence of blindness. The present studied was aimed at studying the various 
causes of ocular disability profile in our part of the country.

In the present study we saw that the mean age of the patients was 42.3 years. The maximum number of patients were in the 41-60 years age group (21 patients i.e. $35.6 \%$ ) followed by $21-40$ years age group (17 patients ie $28.9 \%$ ) followed by $0-20$ years age group (12 patients ie 20.3\%). This showed that young and middle age group people came more likely for the certificate which was due to these patients seeking benefit in jobs due to reservation in jobs for disabled and also for education. Similar findings were noted by Cacodar et $\mathrm{al}^{2}$ Nainiwal et al ${ }^{10}$

We saw the majority of the patients were males with a male:female ratio of $2.28: 1$. This was as seen in other studies too as conducted by Joshi $\mathrm{RS}^{11}$ Cacodar et $\mathrm{al}^{2}$ and Nainiwal et $\mathrm{al}^{10}$. This could be due to the fact that males are more exposed to injuries in the eye and also that males seeked health advice more often than females.

The commonest cause of disability was pthisisbulbi (in 14 patients i.e. 23.7\%) which is an easily preventable cause. Pthisisbulbi was also the commonest cause as seen by Nainiwal et al ${ }^{10}$ This was followed by optic atropy (seen in 11 patients ie $18.6 \%$ ). This was again a preventable cause and also was seen by Nainiwal et al. ${ }^{10}$ The third commonest cause was chorioreinal disorders ( seen in 8 patients i.e.13.6\%).

The limitation of our study was that it was a hospital based study which could not be projected over the population and also was a short study conducted over a period of 3 months.

\section{Conclusion}

From the present study we conclude that mostly young and middle age males came for visual disability certificate in whom the commonest causes of visual handicap iepthisisbulbi and optic atrophy were easily preventable if proper management is instituted at the right time.

\section{References}

1. Dandona L, Dandona R, Naduvilath TJ. Is current eye care policy focus almost exclusively on catarct adequate to deal with blindness in India? Lancet 1998;351:312-6.

2. Cacodar JA. Usgaonkar U, Raitucar TP, Dhulphale N. Clinical Profile of Causes of Visual Impairment at an Urban Health Centre in Goa. DJO. 2019; 29:35-7.

3. Guidelines for evaluation of various disabilities and procedure for certification. The Gazette of India extraordinary. Part 1. Section 1. No 154.

4. Vashist P, Senjam SS, Gupta V, Gupta N, Kumar A. Definition of blindness under National Programme for Control of Blindness: Do we need to revisit it? Indian J Ophthalmol.2017;65:92-6.

5. Thylefors B, Negrel AD, Parrararjasegaram, R, Dadzie KY. Global Data on blindness. Bull. WHO 1995;73:115-21.

6. Murthy GV, Gupta SK, Bachani D, Jose R,Johan N. Current estimates of blindness in India. Br J Ophthalmol.2015;89;257-60.

7. Khanna RC,Maramamula S,Krishnaiah S,GiridharP, Chakrabharti S, Rao GN.Changing trends in the prevalance of blindness and visual impairment in a rural district of India: Systematic observation over a decade. IndianJophthalmol.2012;:492-7.

8. Sapkota YD, Sunuwar M, NaitoM, Akura T, Adhikari HK. The prevalence of blindnessand cataract surgery in Rautahat district, Nepal. Ophthalmic epidemiology. 2010;17:82-9.

9. Casson RJ, Newland HS, Mueke J, McGovern S, Durkin S. Prevalence and causes of blindness and visual impairment in rural Myanmar. Ophthalmology 2007;114:2302-8.

10. Nainiwal SK, Dandaliya MS, Jain P, Singh B, Mittal P, Kumar M, Porwal R. Analysis of Visually Handicap Patients Attending Outpatient Department of a Tertiary Eye care Hospital for Visual Handicap 
Certification In Central Rajasthan, India. Journal of Dental and Mdeical Sciences. 2016;15:36-9.

11. Joshi RS. Causes of visual handicap amongst patients attending outpatient department of a medical college for visual handicap certification in central India. Journal of Clinical Ophthalmology and Research.2013;1(1):17-9. 